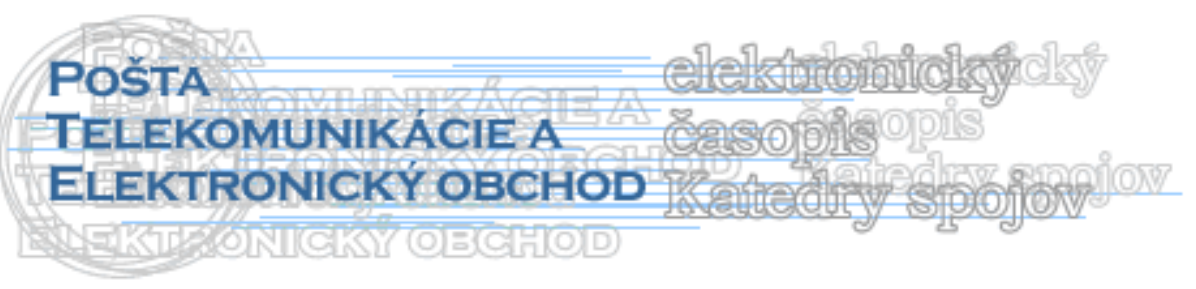

\title{
CESTA K ZNALOSTNEJ SPOLOČNOSTI
}

\author{
Anna Pad'ourová ${ }^{1}$, Margita Majerčáková ${ }^{2}$
}

\section{Úvod}

Ak má byt' Slovensko úspešnou krajinou, musí byt' jej rozvoj postavený na znalostiach a inováciách, musí byt' postavený na znalostnej ekonomike. Inovácie znamenajú nové nápady o tom, ako robit' veci lepšie, rýchlejšie a lacnejšie. Inovácie sú tiež o tom, ako vyrábat' produkty alebo ponúkat' služby s vyššou hodnotou, vyrábat' produkty a ponúkat' služby, ktoré nikdy pred tým neexistovali. Inovácie predstavujú presadzovanie nových nápadov $\mathrm{v}$ podnikaní s kvalifikovanou pracovnou silou, ktorá je schopná nové nápady nielen využit', ale ich aj prinášat'.

Znalosti boli vždy klúčovým faktorom ekonomického a sociálneho rozvoja. Aj predchádzajúce ekonomiky záviseli na znalosti ako farmárčit', ako stavat', ako vyrábat'. Však až v posledných rokoch informačno-komunikačné technológie (IKT) dramaticky zvýšili možnosti spracovávat', skladovat' a prenášat' vel'ké množstvá informácií.

V konkurenčnom prostredí vyhrávajú tí, ktorí vedia využit' znalosti a informácie ako prví. Úspech podnikov a teda v konečnom dôsledku aj celej ekonomiky a spoločnosti je čoraz viac závislý na informačnej infraštruktúre, ktorá je nevyhnutná pre prácu s informáciami. Dnes je Slovenská republika na chvoste rebríčka inovatívnych krajín Európskej únie. Ak chce Slovensko dosahovat' vysoký rast a vysokú konkurencieschopnost', musí výrazne urýchlit' transformáciu na znalostnú ekonomiku, pre ktorú nie je využívanie možností infokomunikačných technológií alternatívou, ale akútnou potrebou.

\section{Úloha vlády a parlamentu}

O tom, či slovenská ekonomika bude konkurencieschopná, či bude znalostná, bude v konečnom dôsledku rozhodovat' komerčná sféra, jednotliví podnikatelia, ktorí sút'ažia a budú sút’ažit' v globálnom prostredí. Úlohou vlády a parlamentu je vytvorit' pre podnikatel'ov a občanov vhodné prostredie, aby mohli uspiet' v tejto sút'aži.

$\mathrm{V}$ súvislosti $\mathrm{s}$ informatizáciou by mala vláda vytvorit' a zlepšovat' prostredie pre konkurencieschopnost' a znalostnú spoločnost'.

1. Minimalizovat' zat’aženie podnikatel'ov a občanov zo strany verejnej správy Konkrétne to znamená:

\footnotetext{
${ }^{1}$ Ing. Anna Pad’ourová, Žilinská univerzita v Žiline, Fakulta Prevádzky a ekonomiky dopravy a spojov, Katedra spojov, Univerzitná 1, 01026 Žilina tel. č.: 041/513 3129, fax: 041/ 5655615 e-mail: Anna.Padourova@,fpedas.utc.sk

${ }^{2}$ Dr. Ing. Margita Majerčákov, Žilinská univerzita v Žiline, Fakulta Prevádzky a ekonomiky dopravy a spojov, Katedra spojov, Univerzitná 1, 01026 Žilina tel. č.: $+421 / 41 / 5133126$, fax: $+421 / 41 / 5655615$ email: Margita.Majercakova@,fpedas.utc.sk
} 
a) Zavedenie služieb eGovernmentu na úrovni štátnej správy a na úrovni samosprávy, ktoré umožnia komunikovat' a vybavovat' úradné záležitosti elektronickou formou.

b) Zrovnoprávnenie použivania elektronických a papierových dokumentov a komunikácie $\mathrm{s}$ papierovými dokumentmi a komunikáciou v reálnom živote. To znamená, aby ich súdy a štátne orgány (a daňové úrady, colné úrady, atd’.) akceptovali ako dôveryhodné a rovnocenné s papierovými.

c) Sproduktívnenie verejnej správy - nutná je zmena procesov so súčasným využitím možností IKT.

Informačno-komunikačné technológie sa stali bežnou súčast'ou života. Či sú to nové podnikatel'ské modely (napríklad nakupovanie prostredníctvom internetu), nové spôsoby vzdelávania, radikálne zvýšenie produktivity v priemysle (napríklad pri navrhovaní a výrobe automobilov, lietadiel), nové metódy zdravotnej starostlivosti (napríklad počítačová tomografia), ul'ahčenie života (napríklad elektronické bankovníctvo, služby eGovernmentu), zvládanie katastrof (monitorovaním a ich simuláciou) alebo zásadne zmenený spôsob komunikácie (mobilné telefóny, e-mail, SMS).

\section{Pripravit' pracovníkov pre dynamicky sa rozvíjajúce odvetvie IKT}

Jedným z pilierov znalostnej a konkurencieschopnej ekonomiky je vyspelé odvetvie IKT. Slovensko má šancu na to, aby IKT priemysel poskytoval vysokokvalifikované služby nielen na domácom trhu, ale aj aby sa stal významným exportérom služieb s vysokou pridanou hodnotou. Na Slovensku sa však silne začína prejavovat' nedostatok kvalifikovaných pracovníkov, čo je nutnou podmienkou pre d'alší rozvoj odvetvia IKT a nové investície v tomto odvetví. Pre väčšinu pracovných pozícil v odvetví IKT nie je potrebné druhostupňové vysokoškolské vzdelanie. Postačuje kvalitné stredoškolské resp. bakalárske vzdelanie. Toto vzdelávanie však okrem odbornej stránky musí zabezpečit' aj dostatočné jazykové znalosti, schopnost' identifikovat', analyzovat' a vyriešit' problémy, vzdelávat' $k$ tvorivosti, inovatívnosti, schopnosti prevziat' zodpovednost'.

Pre rozvoj odvetvia informačných a komunikačných technológií (ako kl’účového odvetvia pre rozvoj konkurencieschopnosti Slovenska a znalostnej spoločnosti) by mala vláda podporit' zmenu profilácie niektorých stredných škôl a bakalárskeho štúdia na informatiku. Podobne by mali byt' podporené rekvalifikačné kurzy pre absolventov stredných a vysokých škôl zamerané na informatiku.

\section{Nedeformovat' konkurenčné prostredie v odvetví IKT}

Odvetvie IKT je najdynamickejším a najviac konkurenčným prostredím tak $\mathrm{v}$ globálnom meradle ako aj na Slovensku. Okrem iného je to dané aj tým, že je minimálne regulované. Pre d'alší dynamický rozvoj odvetvia na Slovensku považujeme za potrebné:

\section{a) Minimalizovat' reguláciu zo strany štátu}

Pre oblast' telekomunikácií je však vhodné podporit' zvýšenie konkurenčného prostredia napríklad umožnením vstupu na trh d’alším konkurenčným operátorom $\mathrm{v}$ oblastiach, ktoré sú podmienené získaním licencie. Akákol’vek regulácia by mala starostlivo posudzovat' zmysluplnost' a rozsah (napr. univerzálna služba v oblasti telekomunikácií).

\section{b) Minimalizovat' intervencie}

Intervencie zo strany vlády ako sú dotácie, príspevky a pod., viac či menej narušujú konkurenčné prostredie, respektíve zvýhodňujú niektorého výrobcu / dodávatel'a alebo technológiu. Akákol'vek intervencia by sa mala starostlivo zvažovat', zohl'adňovat' ochranu investícií a nezasahovanie do konkurenčného prostredia.

\section{c) Nezat’ažovat' odvetvie IKT vynútenými nákladmi}

Vláda $\mathrm{v}$ oblasti telekomunikácí́ od operátorov požaduje niektoré služby súvisiace $\mathrm{s}$ bezpečnost'ou. $\mathrm{V}$ súčasnosti náklady na tieto opatrenia znášajú telekomunikační operátori. Vzhl'adom na to, že sa jedná o službu vyžadovanú vládou, znamená to, že náklady na tieto opatrenia by mal znášat' štátny rozpočet. Zat'ažovanie telekomunikačných operátorov okrem 
iného značne obmedzuje vstup nových komerčných subjektov na trh a tým poškodzuje občanov a podnikatel'ov.

\section{d) Nezat'ažovat' odvetvie IKT nad rámec nevyhnutných povinností vyžadovaných EÚ}

Brzdou odvetvia IKT je zat'ažovanie nad rámec povinností vyžadovaných EÚ alebo bežných $\mathrm{v}$ okolitých krajinách. Ide predovšetkým o oblast' autorských poplatkov a enviromentálnej legislatívy. Vláda by nemala zat’ažovat' podnikatel'ov povinnost'ami nad rámec legislatívy vyžadovanej EÚ alebo platnej v okolitých krajinách a tak znevýhodňovat' slovenských podnikatel'ov voči ich konkurentom iných krajinách.

\section{Kde sa nachádzame?}

V porovnaní s priemerom krajín Európskej únie (53\%) nedosahuje Slovenská republika $(23 \%)$ ani ich polovičnú úroveň v podiele obyvatel'stva so zriadeným prístupom na internet. Z pohl'adu penetrácie domácností vysokorýchlostným internetom (7\%) je situácia ešte horšia. Súvisí to najmä s relatívne vysokou cenou internetu a osobných počítačov vo vzt'ahu ku kúpnej sile. Druhou príčinou je nedostupnost' internetu, a to predovšetkým v miestach s nižšou hustotou osídlenia, ktoré pre poskytovatel'ov pripojenia nie sú z hladiska návratnosti vynaložených investícií zatial' dostatočne atraktívne.

Nízka penetrácia internetu sa okrem domácností týka aj podnikov, v ktorých iba $26 \%$ zamestnancov využíva PC s internetom ako bežný pracovný prostriedok. Príčiny zaostávania SR za EÚ (37\%), nespočívajú ani tak vo fyzickej, alebo cenovej nedostupnosti internetu, ale skôr $\mathrm{v}$ nízkej technologickej úrovni a kvalite mikroekonomických procesov $\mathrm{v}$ podnikoch najmä vo vzt'ahu $\mathrm{k}$ IKT. Z hl'adiska rozvoja informačnej spoločnosti je Slovensko iba $\mathrm{v}$ počiatočnej fáze. Silne zaostáva nielen za pôvodnými, ale aj novými členskými krajinami

Koncepcia rozvoja informačnej spoločnosti členských krajín EÚ je postavená na spoločných troch prioritných oblastiach:

- vytvorenie jednotného európskeho informačného priestoru, ktorý podporuje otvorený a konkurencieschopný vnútorný trh v oblasti informačnej spoločnosti a médií;

- zintenzívnenie inovácií a investícií $\mathrm{v}$ oblasti informačných a komunikačných technológií na docielenie rastu, ako aj početnejších a lepších pracovných miest;

- vybudovanie európskej informačnej spoločnosti pre všetkých občanov, ktorá podporuje rast a zamestnanost' spôsobom, ktorý je v súlade s trvalo udržatel'ným rozvojom a ktorého prioritami sú lepšie verejné služby a zvýšená kvalita života.

\section{Kl'účové faktory rozvoja informačnej spoločnosti v SR}

$\mathrm{Na}$ základe výsledkov analýzy boli identifikované nasledujúce kl’účové faktory rozvoja informačnej spoločnosti v SR.

- modernizácia fungovania verejnej správy využitím možností IKT;

- zrovnoprávnenie elektronických a papierových dokumentov a komunikácie;

- zvyšovanie digitálnej gramotnosti žiakov, študentov a ostatných občanov;

- rozširovanie pokrytia vysokorýchlostného internetu;

- vysoké konkurenčné prostredie v telekomunikačnom sektore;

- vytváranie užitočného obsahu;

- Vzdelávanie pracovníkov pre prácu v silne expandujúcom odvetví IKT

Za jedinečnú šancu urobit' zásadný pozitívny krok v úrovni informatizácie SR a naštartovat' procesy, vedúce $\mathrm{k}$ rastu inovatívnosti a v konečnom dôsledku $\mathrm{k}$ rýchlemu rozvoju znalostnej ekonomiky považujeme využitie EÚ fondov v programovacom období 2007-2013. Akútna potreba rýchleho rozvoja $\mathrm{v}$ oblasti informatizácie je umocnená podcenením tejto 
oblasti V súčasnom programovacom období 2004-2006, kedy podiel výdavkov na informatizáciu z fondov EÚ dosahoval iba 0,96\%. V ostatných krajinách EÚ je $\mathrm{v}$ tomto období na informatizáciu vynakladaných v priemere 7,3\%.

\section{Hlavné úlohy vlády}

- zabezpečit' digitálnu gramotnost' občanov ako jeden $\mathrm{z}$ predpokladov ich uplatnitel'nosti v znalostnej spoločnosti;

- vytvárat' predpoklady, aby občan mal možnost' využívat' možnosti IKT vo svojom živote;

- (eGovernment, eContent, eLearning);

- zabezpečit' dostatok pracovníkov uplatnitel'ných v znalostnej ekonomike;

- zabezpečit' dostatok pracovníkov uplatnitel'ných v rastúcom odvetví IKT;

- pomáhat' samospráve hl'adat' a realizovat' riešenia, ktoré zlepšia plnenie jej funkcií;

- vo vzájomnej spolupráci systémovo riešit' informatizáciu štátnej správy a samosprávy;

- využit' možnosti IKT pre zlepšenie plnenia funkcií štátnej správy vo vzt'ahu k občanom a podnikatel'om;

- využit' možnosti IKT pre sproduktívnenie fungovania štátnej správy samotnej.

\section{Záver}

\section{Prínosy pre občanov}

1. Menšie zat'aženie občanov z pohl'adu vybavovania úradných záležitostí. Zníženie neproduktívneho času stráveného na úradoch. Nižšie náklady na vybavovanie úradných záležitostí. Možnost' vybavit' väčšinu úradných záležitostí na jednom mieste.

2. Nadobudnutie digitálnej gramotnosti a teda vyššia uplatnitel'nost' na trhu práce. Užitočný obsah dostupný na internete, vrátane celoživotného vzdelávania.

3. Menšie daňové zat'aženie občanov.

4. Zvýšenie dostupnosti IKT.

Prínosy pre podnikatel'ov

5. Menšie zat'aženie podnikatel'ov z pohl'adu vybavovania úradných záležitostí. Zníženie neproduktívneho času stráveného na úradoch. Nižšie náklady na vybavovanie úradných záležitostí.

6. Dostatok pracovníkov uplatnitel'ných v meniacej sa ekonomike.

7. Vytvorené dobré podmienky pre eBusiness.

8. Menšie daňové zat'aženie podnikatel'ov.

9. Zvýšenie dostupnosti IKT.

\section{Prínosy pre odvetvie IKT}

10. Dostatok pracovníkov uplatnitel’ných v rozvíjajúcom sa odvetví IKT.

11. Rozširovanie investícií v odvetví IKT.

\section{Prínosy pre štátnu správu}

12. Produktívnejšie fungujúca verejná správa, menej zat’ažujúca podnikatel'ov a občanov.

13. Zvýšenie transparentnosti a zníženie miery korupcie.

14. Zníženie nákladov na štátnu správu a zníženie počtu úradníkov.

\section{Prínosy pre samosprávu}

15. Produktívnejšie fungujúca samospráva, menej zat’ažujúca občanov.

16. Zníženie nákladov na IKT pri súčasnom zásadnom zlepšení IKT v samospráve.

V tomto prípade platí Paretovo pravidlo 20/80. To znamená, že $20 \%$ kl'účových opatrení prinesie $80 \%$ úžitku . 


\section{Literatúra}

[1] ČOREJOVÁ, T. - ŠTOFKOVÁ, K.: On the problem of electronic communications pricing in Slovak Republic. In: Telekomunikacja i poczta jako stymulatory rozwoju egospodarki w Polsce : Szczecin - Darłowo, maj 2005. - Szczecin: Wydział Zarządzania i Ekonomiki Usług, Uniwersytet Szczeciński, 2005. - ISBN 83-7241-477-7. - P. 309-314.

[2] MADLEŇÁK, R., MAJERČAKOVÁ, M.: Informácia a jej prenos : (návody a cvičenia). - 1. vyd. - V Žiline : Žilinská univerzita, 2004. - 133 s., AH 6,44, VH 6,87 : obr., tab. ISBN 80-8070-327-2.

[3] KREMEŇOVÁ, I - - ROSTÁŠOVÁ, M.: Marketing v službách /Marketingový informačný systém /vedecká redaktorka : Tatiana Čorejová./ - 1. vyd. - V Žiline : Žilinská univerzita, 2005. - 110 s., AH 6,95, VH 7,28 : obr., tab. - ISBN 80-8070-358-2.

[4] http://europa.eu.int/information society/eeurope/2005/index en.htm

[5] http://www.telecom.gov.sk/index/go.php?id=651

[6] http://www.minerva.sk/default.aspx?ami=1340\&smi=1343

\section{Grantová podpora}

Príspevok vznikol na základe riešenia výskumného projektu VEGA 1/1265/04 VEGA 1/1265/04 Výskum siet’ových procesov v rámci odvetvových zoskupení firiem v SR, podporeného MŠ SR.

Príspevok vznikol na základe riešenia výskumného projektu VEGA 1/2591/05 Vplyv výberu efektívnej stratégie na udržiavanie konkurencie schopnosti podniku v rámci liberalizácie poštových trhov, podporeného MŠ SR. 